\title{
CONTRIBUIÇÕES DO YOUTUBE PARA O ENSINO DE FÍSICA EM
}

\section{LIBRAS}

Adriana Moreira de Souza Corrêa, Universidade Federal de Campina Grande (UFCG), adriana.korrea@gmail.com

Natália dos Santos Almeida, Universidade Cândido Mendes (UCAM), nataliaalmeida.edu@gmail.com

PALAVRAS-CHAVE: Bilinguismo; Física; Youtube.

\section{INTRODUÇÃO}

O aluno surdo o indivíduo que, por apresentar diminuição considerável na acuidade auditiva, utiliza-se de um sistema linguístico visual-gestual para a comunicação (BRASIL, 2005). Por esta razão, Slomski (2010) defende que a educação para surdos precisa ser planejada e efetivada considerando que a escola precisa possibilitar o aprendizado dos surdos em uma perspectiva bilíngue, ou seja, pautada na aquisição da Língua Brasileira de Sinais Libras, como primeira língua e no aprendizado da Língua Portuguesa, como segunda língua. Esta proposta é apresentada pelo Decreto 5.626/2005 que regulamenta a Lei da Libras.

A estudiosa afirma que a prática na qual apenas a Língua Portuguesa atua como sistema linguístico de mediação dos conhecimentos científicos, deve ser repensada, abrindo possibilidades para o uso da Libras. Isso não implica dizer que a Língua Portuguesa deva ser banida do processo educacional, mas que ambas as línguas, devem ser compreendidas como instrumentos de significação e, por isso, precisam ser utilizadas, separadamente, com escopos definidos. Por esta razão, toda a mediação pedagógica deve estar pautada no uso da Libras e nos recursos visuais e, diante disso, buscamos no YouTube, vídeos que favorecessem a aquisição de conhecimentos em Libras, já que o material disponibilizado pela escola, que é o livro didático, é redigido em Português.

\section{METODOLOGIA}

Considerando o educando surdo representante de uma minoria linguística que se comunica através da Libras, buscamos, neste trabalho, discutir a seguinte questão: quais são os materiais disponíveis no YouTube, que podem mediar as práticas educacionais pautadas na Libras para destes alunos? Para tanto, realizamos uma pesquisa de abordagem qualitativa, de natureza descritiva, utilizando, par coleta de dados, a revisão bibliográfica, que tem como 
objetivo o levantamento de dados sobre determinado assunto (SILVEIRA; CÓRDOVA, 2009). Utilizamos o descritor "Física em Libras" para identificar os materiais disponíveis os quais relacionamos em tabelas a partir dos objetivos e das informações utilizadas para a comunicação da ideia, tais como uso da Libras, português oral e/ou escrito e imagens.

\section{VIIDEOS NO YOUTUBE E O APRENDIZADO DOS ALUNOS SURDOS}

Os PCNs do Ensino Médio (Parte III - Ciências da Natureza, Matemática e suas Tecnologias) ao abordar as competências e as habilidades que devem ser desenvolvidas pelos alunos nesta etapa da escolaridade, traz várias referências as quais destacamos quatro: $1^{\circ}$ ler e interpretar textos de interesse científico e tecnológico; $2^{\circ}$ interpretar e utilizar diferentes formas de representação (tabelas, gráficos, expressões, ícones...); $3^{\circ}$ exprimir-se oralmente com correção e clareza, usando a terminologia correta; $4^{\circ}$ produzir textos adequados para relatar experiências, formular dúvidas ou apresentar conclusões (BRASIL, 2007, p. 29).

Considerando que o aluno surdo é um usuário da Libras como primeira língua, salientamos que a sua compreensão nesta língua será superior do que quando compararmos o seu entendimento na segunda língua. Desta maneira, o uso exclusivo do livro didático, escrito em Português restringe a possibilidade de aquisição de conhecimentos pelos surdos, sendo necessário, o uso de recursos auxiliares que sejam viabilizados em Libras. Assim, buscamos no YouTube, vídeos que mediassem este aprendizado os quais categorizamos em seis grupos: glossários de conceitos utilizados na área da física; aulas de física em Libras (modelos vídeoaulas); gravação de vídeos sobre as temáticas tratadas na área, com a presença do intérprete; interpretação de vídeos já existentes e mostras/relatos de experiências que envolvem a interação entre a matéria e a energia que trabalham as temáticas da área.

Os glossários em Libras, relacionam os termos nas duas línguas possibilitando a retomada do que foi estudado em classe em momentos nos quais o intérprete educacional não está presente e favorecem a ampliação do vocabulário em Língua Portuguesa.

As aulas no formato de vídeo-aulas podem ser divididas em: aulas em Libras e aulas interpretadas para a Libras. As primeiras permitem rever o conteúdo abordado no livro (em Português) e que foi trabalhado em classe (em Libras e em Português), só que, neste formato, a língua de instrução passa a ser a Libras, facilitando a compreensão do surdo. Entretanto, para que o professor (não usuário desta língua) possa indicar o vídeo para o aluno, necessitará do auxílio do intérprete da Libras a fim de avaliar se o material se adequa ao que foi estudado. 
Já as aulas interpretadas para a Libras, o docente tem maior autonomia para a análise do conteúdo do vídeo, tendo em vista que este é apresentado na perspectiva bilíngue. Este material, assim como os vídeos que tratam da temática e foram interpretados ou gravações de aulas na quais a imagem do docente e do intérprete foram registradas simultaneamente, podem ser utilizados ainda na classe inclusiva e contribuir para a divulgação da Língua de Sinais e valorização do bilinguismo na escola.

Por fim, para relacionar a teoria à prática, os vídeos que mostram experiências sobre a temática sendo realizadas e descritas em Libras são úteis pois aproximam os conceitos à prática, utilizam-se da visualidade e favorecem a compreensão do surdo.

\section{CONSIDERAÇÕES FINAIS}

As tecnologias estão presentes hodiernamente e este recurso pode ser utilizado para favorecer o ensino das disciplinas escolares, entre elas, a física. Sabendo que o surdo é usuário de uma língua visual-gestual, o uso de vídeos corresponde a um aliado importante pois prioriza a compreensão do conteúdo na primeira língua, a Libras, bem como favorece a divulgação deste sistema linguístico entre os colegas ouvintes, promovendo uma educação bilíngue e inclusiva. Este recurso permite ainda a retomada dos conhecimentos, promovendo a autonomia de estudos nos momentos nos quais o discente surdo não dispõe do serviço do intérprete da Libras, ampliando as fontes de pesquisa. Contudo, é necessário que o docente esteja atento aos materiais disponibilizados neste site, indicando os vídeos apenas após a análise do conteúdo. Este recurso pode também incentivar o educador a repensar a forma de ensinar e avaliar estes alunos à medida que propõe que esta análise seja mediada pela Libras.

\section{REFERÊNCIAS}

BRASIL. Parâmetros Curriculares Nacionais (Ensino Médio): Ciências da Natureza, Matemática e Suas Tecnologias. 1998. Disponível em: < http://portal.mec.gov.br/seb/arquivos/pdf/ciencian.pdf>. Acesso em: 13 abr. 2017.

Decreto $\mathbf{n}^{\mathbf{0}}$ 5.626, de 22 de dezembro de 2005. Disponível em: < https://presrepublica.jusbrasil.com.br/legislacao/96150/decreto-5626-05>. Acesso em: $11 \mathrm{de}$ agosto de 2017.

SILVEIRA, D. T.; CÓRDOVA, F. P. A pesquisa científica. In. GERHARDT, T. E. SILVEIRA, D. T. Métodos de Pesquisa. Porto Alegre: Editora da UFRGS, 2009.

SLOMSKI, V. G. Educação Bilíngue para Surdos: concepções, implicações e práticas pedagógicas. Curitiba: Juruá, 2010. 